\title{
Immunomodulatory effects of the botanical compound LCSIOI: implications for cancer treatment
}

\author{
Itzchak H Rachmut' \\ Noah Samuels ${ }^{2, *}$ \\ Steven J Melnick ${ }^{3}$ \\ Cheppail Ramachandran ${ }^{4}$ \\ Yedida Sharabi' \\ Anya Pavlovsky' \\ Yair Maimon ${ }^{5}$ \\ Jacob Shoham' \\ 'The Gonda-Goldschmied Center, \\ Bar-Ilan University, Ramat-Gan, \\ Israel; ${ }^{2}$ Center for Integrative \\ Complementary Medicine, Shaare \\ Zedek Medical Center, Jerusalem, \\ Israel; ${ }^{3}$ Department of Pathology, \\ ${ }^{4}$ Research Institute, Miami Children's \\ Hospital, Miami, FL, USA; ${ }^{5}$ Refuot \\ Integrative Medical Center, Tel Aviv, \\ Israel \\ *Joint first author
}

This article was published in the following Dove Press journal:

OncoTargets and Therapy

23 April 2013

Number of times this article has been viewed

Objective: To examine the effects of LSC101, a botanical compound, on adaptive and innate immunity.

Materials and methods: LCS101 preparations were tested for batch-to-batch consistency using high-performance liquid chromatography. T-cell activation was quantified in murine spleen cells using ${ }^{3} \mathrm{H}$-thymidine incorporation, and cytokine production analyzed with enzyme-linked immunosorbent assay. Natural killer cell activity was tested on human blood cells using flow cytometry, and cytotoxicity measured by 3-(4,5-dimethylthiazol-2-yl)-2,5-diphenyltetrazolium bromide and apoptosis using a FACSCalibur. Effects on interferon- $\gamma$ production in fluorouracil/ doxorubicin-treated mice were tested with enzyme-linked immunosorbent assay.

Results: High-performance liquid chromatography analysis demonstrated batch-to-batch consistency. T-cell proliferation was increased, and a dose-dependent activation of natural killer cells and macrophage tumor necrosis factor- $\alpha$ secretion were observed with LCS101 treatment. Interferon- $\gamma$ levels, reduced following fluorouracil treatment, were corrected in treated animals. No toxicity or compromised treatment outcomes were associated with LCS101 exposure.

Conclusions: LCS101 demonstrated significant effects on a number of immune processes. Further research is needed in order to understand the molecular immunomodulatory pathways affected by this compound, as well as clinical implications for treatment.

Keywords: botanical compound, immunomodulation, T-cell immunity, NK cells, interferon-gamma, TNF-alpha

\section{Introduction}

It has long been understood that disturbances in the body's immune system can increase the risk for cancer. ${ }^{1,2}$ Factors that promote innate immunity or inhibit the adaptive immune response and interfere in the interaction between the two systems are believed to be responsible for this causal relationship..$^{2,3}$ The innate immune system is considered the body's first line of defense against any antigenic challenge, and involves granulocytes, dendritic cells (DCs), macrophages, natural killer (NK) cells, and mast cells. The adaptive immune system consists of humoral immunity mediated by B lymphocytes and cell-mediated immunity mediated by $\mathrm{T}$ lymphocytes.

Chronic inflammation can interrupt the balance between the innate and adaptive immune systems, which are connected through a form of "cross talk" and monitored by DCs presenting foreign antigens to adaptive lymphoid immune cells, as well as NK cells, which promote DC maturation. This can lead to irreversible changes in tissues with excessive remodeling, loss of tissue architecture, protein and DNA alterations due to oxidative stress, and an increased risk of cancer development. ${ }^{3}$ The presence
Correspondence: Yair Maimon Refuot Integrative Medical Center, 18 Feinstein Street, Tel Aviv

69123 , Israel

Tel +97237440888

Fax+9723677 7768

Email yair@tcm.org.il which permits unrestricted noncommercial use, provided the original work is properly cited. 
of increased innate immune activity correlates directly with angiogenesis and a poor prognosis for cancer patients. ${ }^{4-6}$

A number of botanical-based products have been shown to have anticancer effects that include proapoptotic activity, inhibition of angiogenesis, and stimulation of the immune response. ${ }^{7,8}$ LCS101 is a botanical compound that was developed for use in cancer patients, and is based on the principles of traditional Chinese medicine. The formula contains extracts from the following herbs: Astragalus membranaceus, Atractylodes macrocephala, Citrus reticulate, Glehnia littoralis, Ligustrum lucidum, Lycium chinense, Millettia reticulata, Oldenlandia diffusa, Ophiopogon japonicus, Paeonia lactiflora, Paeonia obovata, Poriae cocos, Prunella vulgaris, and Scutellaria barbata. Extracts are manufactured in accordance with good manufacturing practice conditions, and imported under license (Zen Herbs, Rehovot, Israel) in accordance with the regulations of the Israel Ministry of Health. All batches are analyzed and certified to be free of heavy metals, microbial contamination, pesticide residues, and mycotoxins. The herbal components of LCS101 are considered to be safe for human consumption, and have not been found to alter the bioavailability or outcomes of anticancer drugs. ${ }^{9}$
An in vitro model found a dose-dependent inhibitory effect with LCS101 treatment on cell survival in three human breast carcinoma cell lines (MDA-231, MDA-453, and T47D). LCS101 also demonstrated a dose-dependent inhibition of cell growth in a T47D cell line, and an increase in the percentage of cells with subdiploid DNA content, the hallmark of apoptosis, in a dose-dependent manner. ${ }^{10}$ In an in vivo murine breast cancer model, the addition of LCS101 to doxorubicin was shown to significantly improve peripheral neutrophil counts, as well as preserving splenic erythrocyte and leukocyte counts (unpublished data). In a randomized, double-blind, placebo-controlled clinical trial, LCS101 was shown to significantly reduce anemia and neutropenia in 65 female patients with locally advanced breast cancer receiving anthracycline and taxane-based treatment regimens. The compound was found to be safe and well tolerated. ${ }^{11}$

The exact mechanism by which LCS101 inhibits cancer cells is not fully understood. Many LCS101 components have been shown to have immunomodulatory effects (Table 1). The purpose of the present study was to examine the effects of LCS101 on various components of the innate and adaptive immune systems.

Table I Effects of LCSIOI components on the immune system

\begin{tabular}{|c|c|c|}
\hline Compound & Immune effects & References \\
\hline $\begin{array}{l}\text { Astragalus } \\
\text { membranaceus }\end{array}$ & $\begin{array}{l}\text { Increases activity of macrophages, phagocytes and NK cells; increases antitumor } \\
\text { effects of IL-2 }\end{array}$ & $12-15$ \\
\hline $\begin{array}{l}\text { Atractylodes } \\
\text { macrocephala }\end{array}$ & $\begin{array}{l}\text { Promotes T-helper lymphocyte proliferation, antibody production, and cytokine } \\
\text { secretion }\end{array}$ & 16,17 \\
\hline Citrus reticulate & $\begin{array}{l}\text { Increases T-cell (CD4/8) proliferation and IFN- } \gamma \text { and TNF- } \alpha \text { production; reduces } \\
\text { postradiation IL-I } \beta \text {, IL-6, TNF- } \alpha \text { levels }\end{array}$ & 18 \\
\hline Glehnia littoralis & $\begin{array}{l}\text { Reduces inflammatory-related cytokine production, neutrophil-mediated MPO } \\
\text { activity, TPA-induced inflammatory damage, and acetate-induced vascular permeability }\end{array}$ & 19,20 \\
\hline Lycium chinense & Increases $\mathrm{T}$ - and B-cell mitogenic stimuli (CD3, CDI9, CD4, and CD8 $)$ & 21 \\
\hline Ligustrum lucidum & Increases local GVH reaction & 12 \\
\hline Millettia reticulata & $\begin{array}{l}\text { Increases } \mathrm{CCl} \text {-induced anti-inflammatory effects (COX-2, NO synthase, } \\
\text { myeloperoxidase) }\end{array}$ & 22 \\
\hline Oldenlandia diffusa & Increases macrophage production of IL-6, TNF- $\alpha$, and macrophage oxidative burst & 14,23 \\
\hline Ophiopogon japonicus & Increases murine splenic weight; reduces cyclophosphamide-induced leukopenia & 24 \\
\hline Paeonia lactiflora & $\begin{array}{l}\text { Increases anti-inflammatory effects, NF-KB activation in B cells; attenuates dendritic } \\
\text { cell maturation }\end{array}$ & 25,26 \\
\hline Paeonia obovata & None found & \\
\hline Poriae cocus & $\begin{array}{l}\text { Increases phagocyte, thymus, splenic indices; increases murine spleen antibody } \\
\text { production and delayed-type hypersensitivity reaction; reduces tumor-associated } \\
\text { macrophage suppression }\end{array}$ & 27 \\
\hline Prunella vulgaris & $\begin{array}{l}\text { Increases monocyte/macrophage response, protein levels of inducible nitric oxide, } \\
\text { and mRNA for TNF } \alpha \text {; reduces ConA, LPS, and OVA-induced splenocyte } \\
\text { proliferation; significantly reduces total } \lg G, \lg G I \text { and } \lg G 2 b \text { levels in immunized mice }\end{array}$ & $28-30$ \\
\hline Scuttellaria barbata & $\begin{array}{l}\text { Increases post-5-FU thymus and spleen indices; increases NK cell activity; reduces } \\
\text { lymphocyte proliferation and splenocyte NK, IL-2 activity }\end{array}$ & 31 \\
\hline
\end{tabular}

Abbreviations: NK, natural killer; IL, interleukin; TNF, tumor necrosis factor; MPO, myeloperoxidase; TPA, I2-O-tetradecanoyl-phorbol-I3-acetate; GVH, graft-versushost; COX, cyclooxygenase; ConA, concanavalin A; LPS, lipopolysaccharide; OVA, ovalbumin; Ig, immunoglobulin; 5-FU, fluorouracil. 


\section{Materials and methods \\ Experimental materials \\ Reagents}

The fluorouracil (5-FU) in phosphate-buffered saline (PBS), concanavalin A (ConA), ethyl acetate ammonium formate, MTT 3-(4,5-dimethylthiazol-2-yl)-2,5-diphenyltetrazolium bromide, propidium iodide, DNase-free RNaseA, and 0.1\% triton X-100 in PBS were purchased from Sigma-Aldrich Israel (Rehovot, Israel). The enzyme-linked immunosorbent assay (ELISA) kits for quantitation of murine interleukin (IL)-10 and tumor necrosis factor (TNF)- $\alpha$ kits were purchased from Peprotech Asia (Rehovot, Israel), and mouse IFN- $\gamma$ was purchased from Abcam (Zotal, Tel Aviv, Israel). Trichloroacetic acid, acetonitrile, high-performance liquid chromatography (HPLC) Supra grade, water, HPLC grade, and methanol were purchased from Biolab (Jerusalem, Israel). Doxorubicin was purchased from Ebewe Pharma (Unterach, Austria). Ultima Gold scintillation liquid was purchased from Lumitron (Petah Tikva, Israel), and the HPLC column Microsorb-MV 100-5 C18 from Varian (Palo Alto, CA, USA). CD56-FITC/CD69-PE/CD45-PerCP antibody reagent was purchased from Becton Dickinson Biosciences (San Jose, CA, USA). Immnunoprep kit and flow cytometry reagents were from Beckman Coulter (Miami, FL, USA).

\section{Animal and human subjects}

Adult Balb/C mice (25-35 g, age 6-10 weeks), raised through internal breeding, were housed in cages under controlled temperature and humidity conditions, with a 12-hour:12-hour light:dark cycle. Access to food and water was given ad libitum. All of the procedures were conducted according to guidelines of the animal ethics committee of Bar Ilan University, Ramat Gan, Israel.

Blood samples (3-4 mL) from four healthy volunteers were collected in a heparin-coated vacutainer. Authorization for the procedure was obtained from the institutional review board at Miami Children's Hospital, with a stipulation for nonidentification of the participants.

\section{Experimental methods \\ Quantification of LCS101 preparations}

Extracts of LCS101 were lyophilized and rehydrated in $2 \mathrm{~mL}$ double-distilled water. The solution was mixed with ethylacetate 1:5 and the organic phase was separated, evaporated, and rehydrated in double-distilled water-methanol solution (50:50). The solution was analyzed for consistency using HPLC with the Microsorb-MV 100-5 C18 column and moving phase of acetonitrile-ammonium formate (Biolab) at a rate of $1 \mathrm{~mL} /$ minute and read at a diode array detector ultraviolet (DAD UV) at 260, 280, and $310 \mathrm{~nm}$.

\section{Cell cultures}

Spleen cells isolated from Balb/C mice were cultured in Roswell Park Memorial Institute medium with 10\% fetal bovine serum (FBS) and antibiotics, in a humidified 5\% $\mathrm{CO}_{2}$ incubator at $37^{\circ} \mathrm{C}$. Spleens were ground and red blood cells lysed with $0.8 \%$ ammonium chloride in PBS. A RAW 264.7 monocyte cell line was grown in Dulbecco's modified Eagle's medium (DMEM) with 10\% FBS, 100 units $/ \mathrm{mL}$ penicillin, and $100 \mu \mathrm{g} / \mathrm{mL}$ streptomycin. Human blood samples $(250 \mu \mathrm{L})$ were incubated in 48 -well plates, and cultures incubated at $37^{\circ} \mathrm{C}$ in a $\mathrm{CO}_{2}$ incubator for 24 hours with incremental concentrations of LCS101. A sample treated with IL-2 $(1 \mathrm{ng} / \mathrm{mL})$ was used as control.

\section{Measurement of T-cell activation}

Spleen cells were cultured with $10 \mu \mathrm{g} / \mathrm{mL}$ ConA (SigmaAldrich) and LCS101. After 48 hours, a fresh medium was provided and $5 \mu \mathrm{Ci} / \mathrm{mL}$ of ${ }^{3} \mathrm{H}$-thymidine added, and then washed after 2 hours with PBS and incubated with ice-cold $7.5 \%$ trichloroacetic acid (Biolab) at $4{ }^{\circ} \mathrm{C}$ for another 20 minutes. The cells were then washed with ice-cold ethanol and lysed with $0.5 \mathrm{M} \mathrm{NaOH}$. The radioactivity in the cell lysate, corresponding to cellular ${ }^{3} \mathrm{H}$-thymidine incorporation, was measured with Ultima Gold scintillation liquid in a $\beta$-counter (1600 TR; Packard, San Diego, CA, USA).

\section{Measurement of NK cell activation}

Human blood samples $(250 \mu \mathrm{L})$ were incubated in 48-well plates with incremental concentrations of LCS101, with IL-2 $(1 \mathrm{ng} / \mathrm{mL}$ ) used as control. After 24 hours, $20 \mu \mathrm{L}$ of specific antibody mix (CD56-FITC/CD69-PE/CD45-PerCP NK-cell activation; Becton Dickinson) was dispensed into separate flow tubes, and $50 \mu \mathrm{L}$ mixed with the antibody and incubated for 30 minutes at room temperature. The blood-antibody mix was lysed in a Coulter Epics Q-prep workstation (Beckman Coulter) using an Immunoprep kit and analyzed on an Elite flow cytometer (Beckman Coulter) using a three-color protocol. Cells positive for fluorescein isothiocyanate, $\mathrm{PE}$, and PerCP were gated as activated NK cells, and the percentage of activated NK cells plotted against LCS101 concentrations and IL-2.32

\section{Determination of cytokine activity}

Cytokine production in RAW 264.7 macrophages was examined using the following methodology: murine spleen 
cells were cultured in DMEM medium 0.5\% FBS (starvation medium) overnight, followed by treatment with and without lipopolysaccharide and LCS101 for 24 hours. The plates were centrifuged and the supernatant analyzed for cytokine secretion. Cytokine levels were measured using murine IL-10 and TNF- $\alpha$ ELISA development kits (Peprotech Asia) and mouse IFN- $\gamma$ using an Abcam Elipair kit (Zotal).

\section{Measurement of cell proliferation}

(MTT) and apoptosis

Cells were grown in 96-well plates for 24 hours with incremental concentrations of LCS101. The medium was removed, and $5 \mu \mathrm{g} / \mathrm{mL}$ MTT (Sigma-Aldrich) was added to each plate and incubated at $37^{\circ} \mathrm{C}$ for 20 minutes. The blue crystals that formed were dissolved in $100 \mu \mathrm{L}$ DMSO, and absorbance read in a plate reader at $570 \mathrm{~nm}$. A separate group of murine spleen cells was washed with PBS and mixed with propidium iodide solution containing $20 \mu \mathrm{g} / \mathrm{mL}$ propidium iodide, DNase-free RNaseA $(200 \mu \mathrm{g} / \mathrm{mL})$, and $0.1 \%$ triton $\mathrm{X}-100$ in PBS (all from Sigma-Aldrich). Cell-cycle analysis was conducted using a FACSCalibur (Becton Dickinson). The percentage of apoptotic cells was determined according to the sub- $\mathrm{G}_{1}$ population, using cell-cycle analysis.

\section{Measurement of interferon- $\gamma$ production}

Intraperitoneal (IP) injections were administered to study mice, with either $200 \mathrm{mg} / \mathrm{kg}$ 5-FU in PBS (Sigma-Aldrich), $5 \mathrm{mg} / \mathrm{kg}$ doxorubicin (Ebewe Pharma), or PBS alone. One milligram/mL of LCS101 was added to the drinking water, to which access was granted ad libitum. Animals were monitored carefully every 3-5 days for any changes in behavior or body weight. The mice were killed after 14 days with $\mathrm{CO}_{2}$, and the splenocytes removed and cultured with
Con-A for 72 hours. IFN- $\gamma$ levels in the culture medium were measured by ELISA.

\section{Statistical methods}

The mean \pm standard deviation estimates were calculated from at least three separate experiments, performed in triplicate. The data were collated in a Microsoft Excel 2007 file and analyzed using a Student $t$-test. A $P$-value $<0.05$ was considered to be statistically significant.

\section{Results}

\section{Consistency of LCSIOI batches}

HPLC analysis of three LCS101 batches demonstrated standardization of the various batches, with comparable levels of absorbance observed at 260,280, and $310 \mathrm{~nm}$, as well as peaks demonstrating lower levels of absorbance (Figure 1).

\section{Effect of LCSIOI on T-cell proliferation}

Murine spleen T-cell proliferation, as measured by ${ }^{3} \mathrm{H}$-thymidine incorporation assay, was increased with LCS101 treatment (Figure 2A).

\section{Effect of LCSIOI on NK cell activation}

An increase in NK cell activity was observed with the addition of LCS101 to human blood cell cultures, as expressed by the NK cell-activation marker CD69. Fluorescence-activated cell-sorter analysis of the human peripheral leukocytes studied found dose-dependent NK cell activation, with $2 \%$ activation in untreated samples, $12 \%$ in IL-2 treated cells, and $18 \%$ with LCS101 treatment at a dose of $200 \mu \mathrm{g} / \mathrm{mL}$ (Figure 2B).

\section{Effect of LCSIOI on cytokine activity}

A dose-dependent increase in the secretion of TNF- $\alpha$ from RAW264.7 macrophages was observed with LCS101

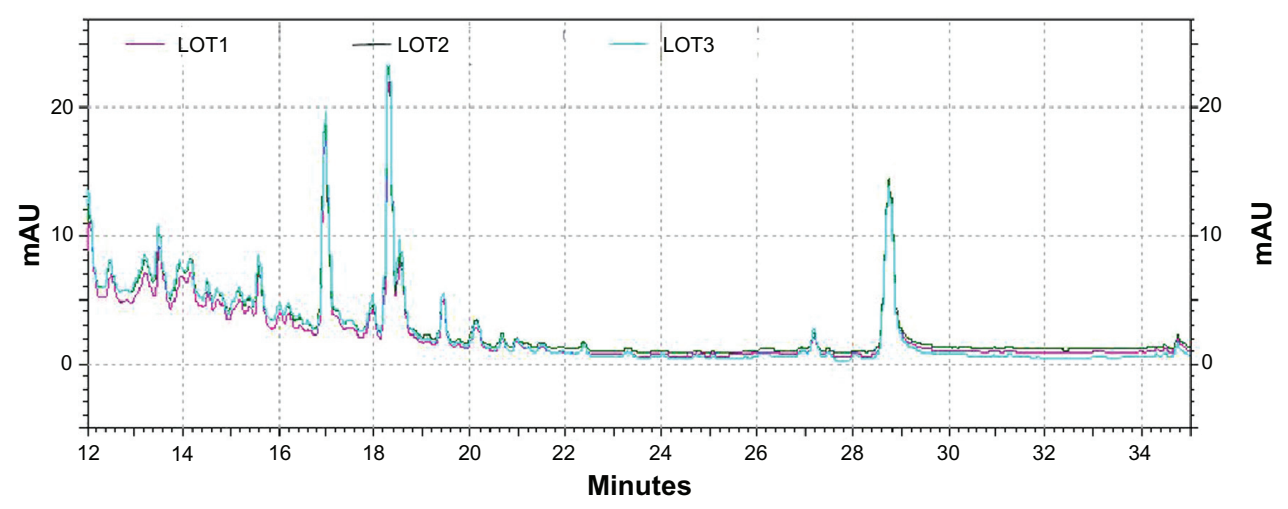

Figure I High-performance liquid chromatography spectrogram of three LCSI0I batches, using a CI8 column and moving phase of acetonitrile-ammonium formate ( $1 \mathrm{~mL} /$ minute) and read at a diode array detector-ultraviolet (DAD-UV) of 260, 280, and $310 \mathrm{~nm}$. 


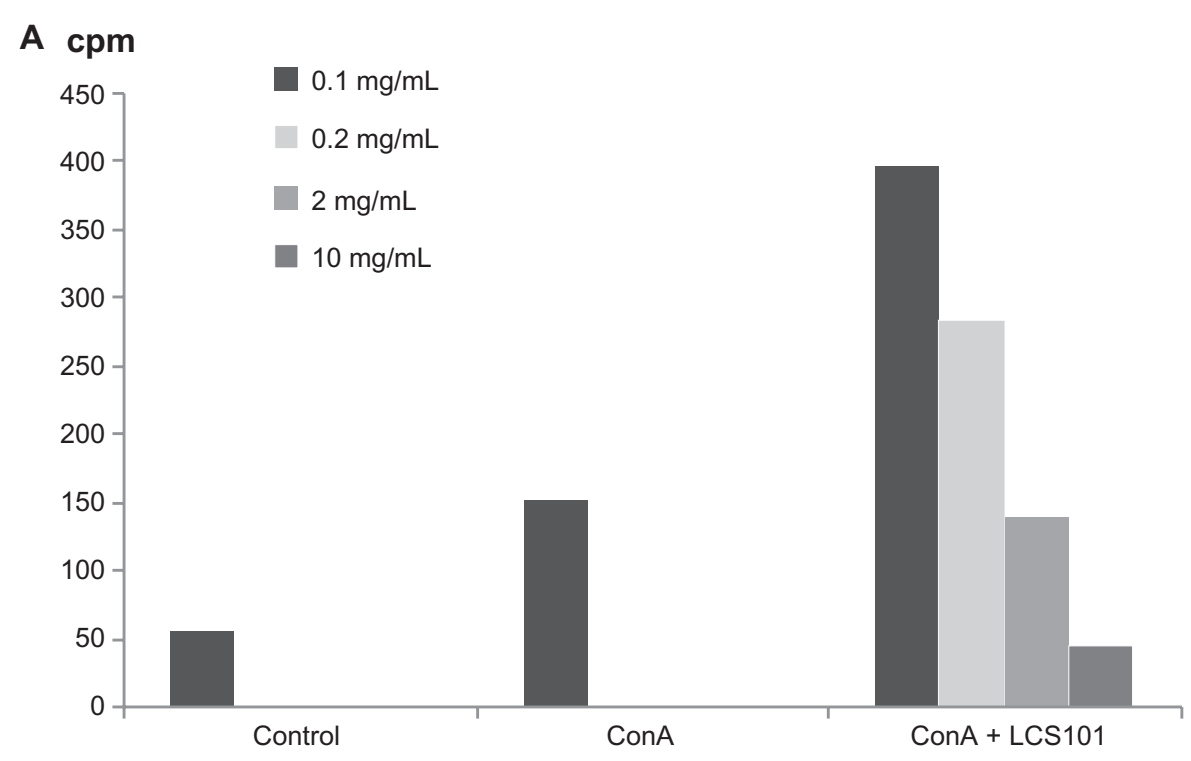

B \% activation

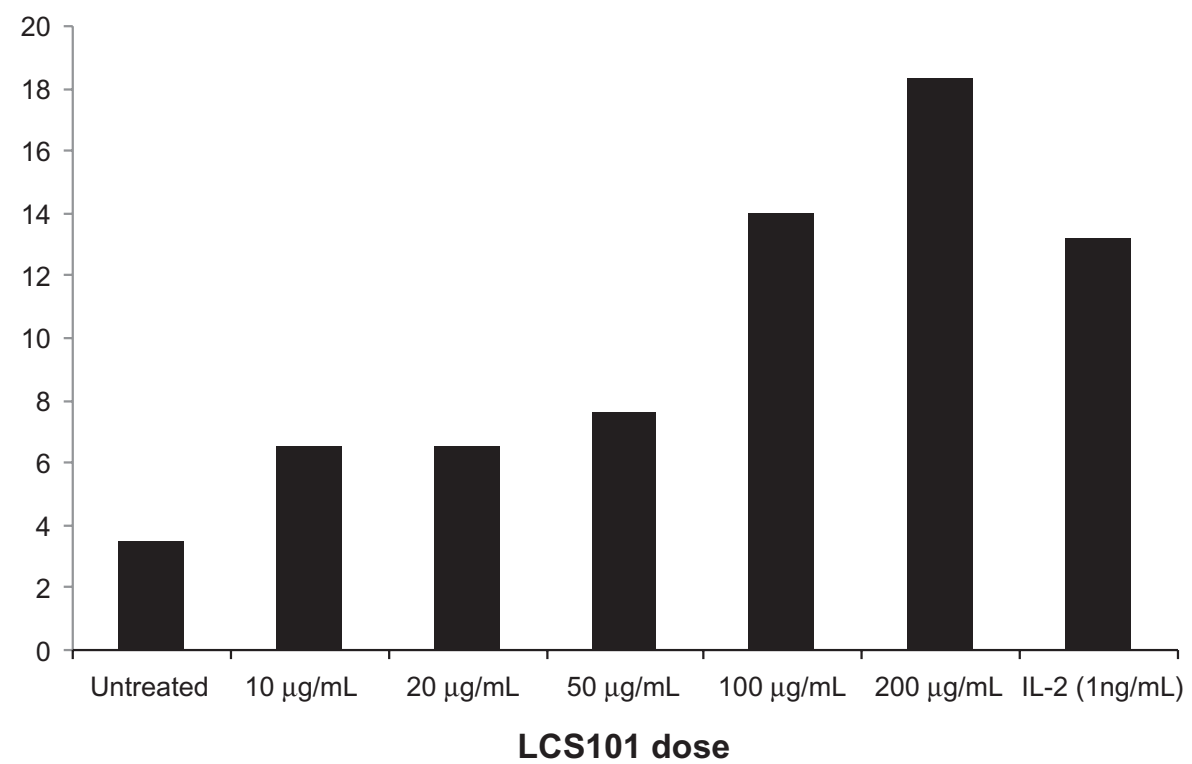

Figure 2 Effect of LCSIOI on (A) murine T-cell activation, as seen via ${ }^{3} \mathrm{H}$-thymidine incorporation; (B) human natural killer cell activation, as seen by the expression of the natural killer cell-activation marker CD69.

Note: Interleukin $2(\mathrm{I} \mathrm{ng} / \mathrm{mL})$ was used as a positive control.

Abbreviation: ConA, concanavalin A; cpm, counts per minute.

treatment, with TNF- $\alpha$ levels increasing 100 -fold when compared to untreated cells (Figure 3). Secretion of IL-10 was not affected by treatment with the study compound.

\section{Effect on IFN- $\gamma$ production following 5-FU/doxorubicin exposure}

IFN- $\gamma$ levels in ConA-treated splenocytes were significantly reduced in mice treated with IP 5-FU, and were unaffected by those that received IP doxorubicin treatment. The levels of IFN- $\gamma$ were corrected following exposure to LCS101 in mice treated with 5-FU, and increased further in those treated with doxorubicin (Figure 4A and B).

\section{Toxicity of LCSIOI treatment (MTT, apoptosis, adverse events)}

No effect was observed regarding growth or function of ConA-stimulated murine splenic $\mathrm{T}$ cells, and no cell toxicity was found in MTT or cell apoptosis. No visible signs of toxicity, such as sedation/immobility or irritability/ hyperactivity were observed following exposure to LCS101, 


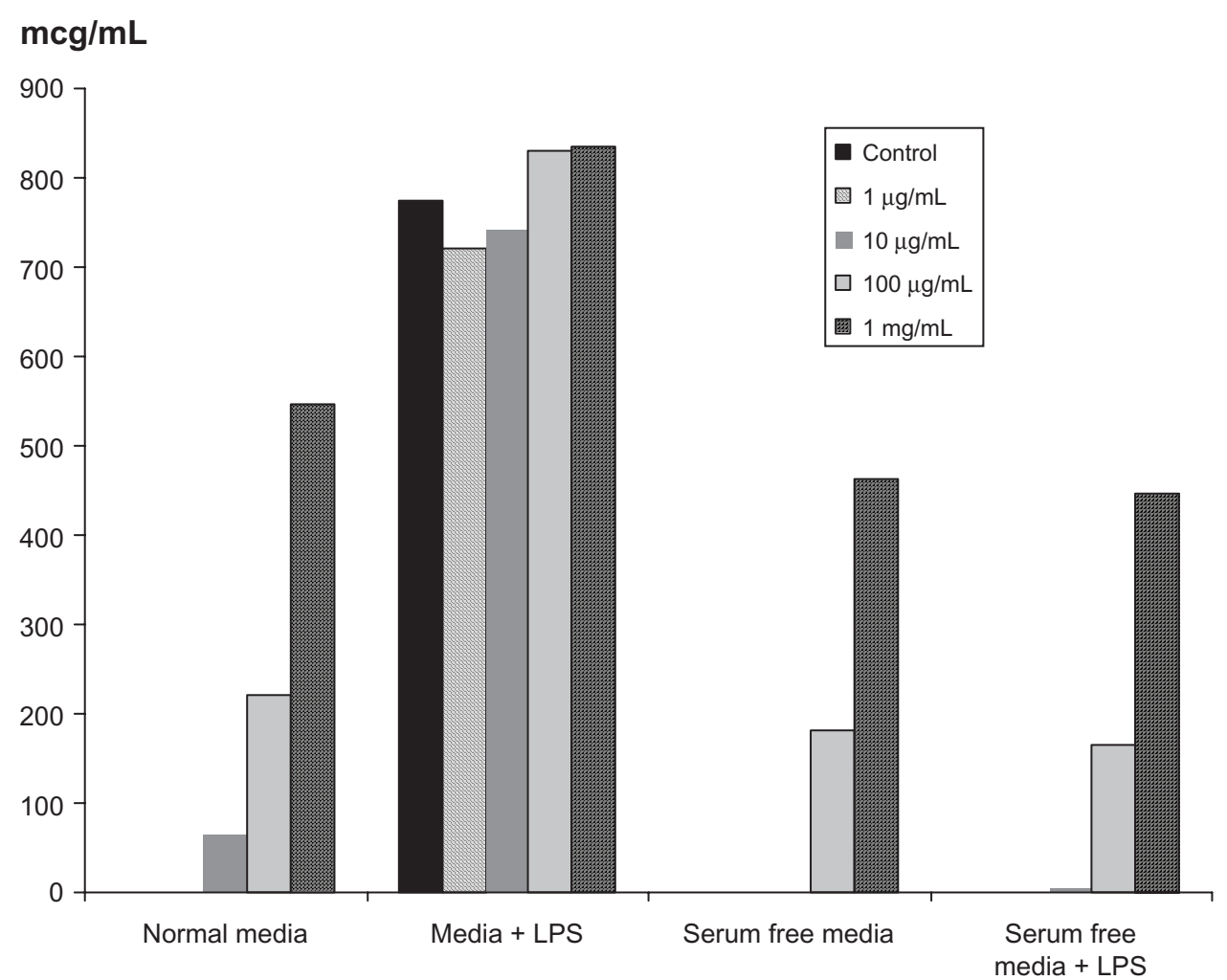

Figure 3 Effect of LCSIOI on tumor necrosis factor- $\alpha$ secretion in RAW 264.7 macrophages. Abbreviation: LPS, lipopolysaccharide.

including at higher doses of the compound. No difference in weight was observed between treated spleens and controls, though a trend for reduced tumor mass was observed with LCS101 treatment which was not statistically significant.

\section{Discussion}

Treatment with the botanical compound LCS101 has been observed to result in a number of immunomodulatory effects in both in vitro and in vivo models. LCS101 has been shown in prior research to have anticancer effects in an in vitro model, ${ }^{10}$ as well as protective effects against chemotherapyinduced hematological toxicities. ${ }^{11}$ The exact mechanism of these outcomes is as yet unclear, though it is likely that the effects of the compound on the immune response may have important indirect anticancer effects.

In the present study, LCS101 was found to increase murine splenic T-cell proliferation, as measured by ${ }^{3} \mathrm{H}$-thymidine incorporation assay. Adaptive T-cell immunity is important in the fight against cancer, particularly stimulation of the Th1 pathway. Direct inhibition of tumor growth may result from antitumor cytotoxic-T-cell activity and cytokine-mediated lysis of tumor cells. In contrast, regulatory T cells that suppress antitumor T-cell responses can promote tumor development by humoral immune responses, which increase chronic inflammation in the tumor microenvironment. ${ }^{3}$ Tumor infiltration with adaptive immune cells such as $\mathrm{T}$ lymphocytes is associated with an improved prognosis. ${ }^{33-36}$

A number of LCS101 components have been shown to augment the adaptive immune response to antigen challenge. The $\beta$ - $(1 \rightarrow 3)$-D-glucan of Poriaecocos, as well as the components Ophiopogon japonicus and Oldenlandia diffusa, have been shown to increase murine splenic mass. ${ }^{14,24,27}$ Increased lymphocyte production and activity have been observed with Ligustrum lucidum following ConA stimulation, ${ }^{12}$ and flavonoids in Astragalus membranaceous have been shown to promote lymphocyte proliferation, as well as raise T-cell counts, regulate T-cell subsets, and elevate lymphokine activated killer cell-inducing activity induced by IL-2. ${ }^{37,38}$ Atractylodes macrocephala has been shown to stimulate lymphocyte proliferation, antibody production, and cytokine secretion in vitro, showing a preferential stimulation of Th1-type immune responses. ${ }^{16,17}$ Finally, the component Lycium chinense has been shown to stimulate Th1 cytokine production. ${ }^{39}$

In the current study, LCS101 was found to induce a dosedependent upregulation of NK cell activation in the blood cells of healthy human subjects. NK cells are considered to be a central mediator in the "cross talk" between the adaptive and the innate immune systems, and play an important role 


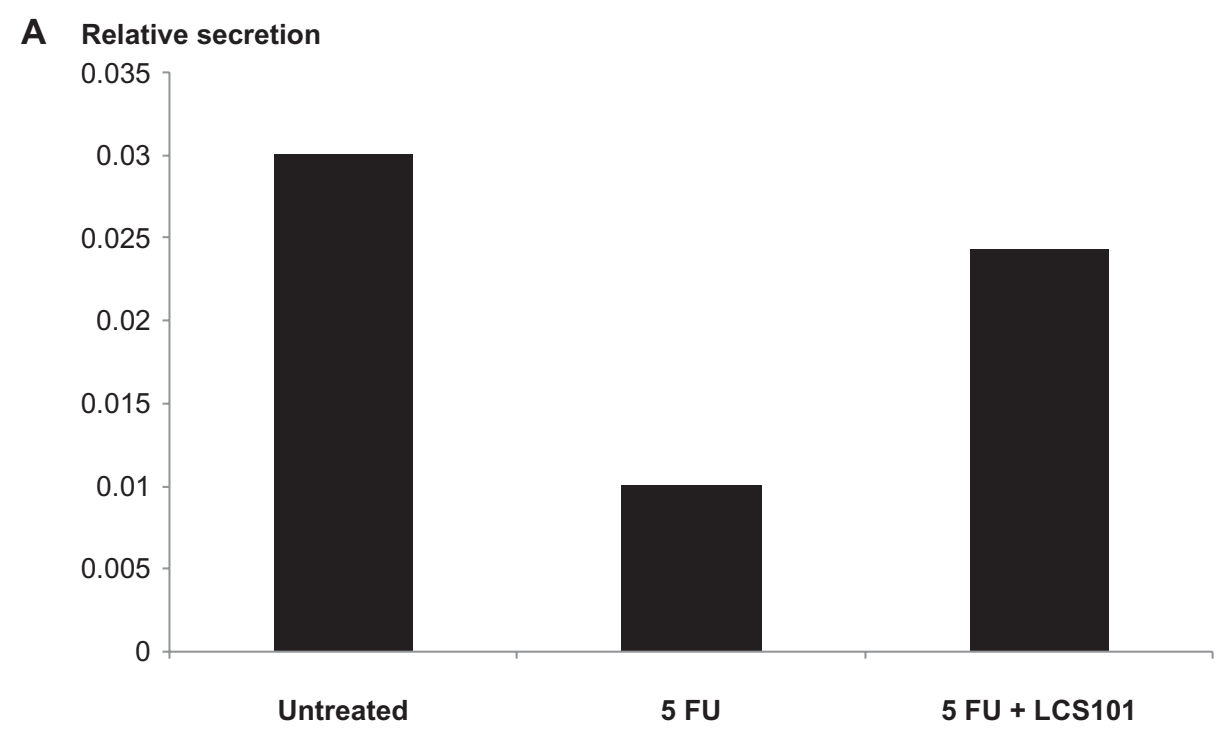

B Relative secretion

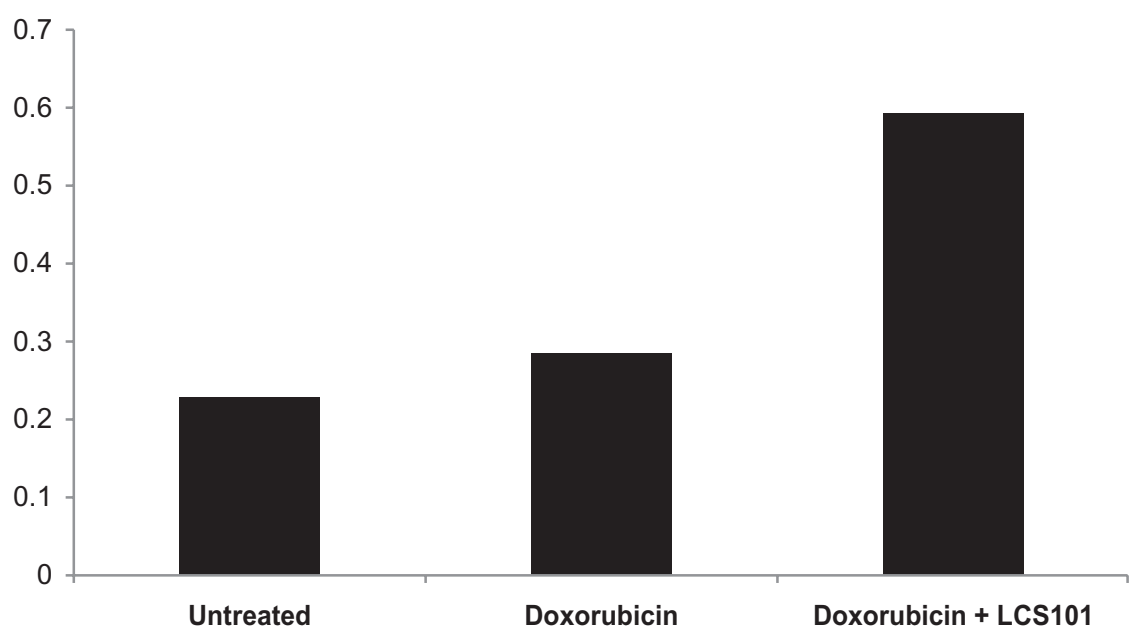

Figure 4 Effect of LCSIOI on postchemotherapy interferon- $\gamma$ production, as measured by enzyme-linked immunosorbent assay. The agents used were (A) intraperitoneal fluorouracil (5-FU; $200 \mathrm{mg} / \mathrm{kg}$ ); and (B) intraperitoneal doxorubicin $(5 \mathrm{mg} / \mathrm{kg})$.

in the inhibition and killing of tumor cells. ${ }^{40}$ The LCS101 component Astragalus membranaceus has been shown to stimulate NK-cell activity in human peripheral lymphocytes, as well as restoring steroid-inhibited NK-cell activity. ${ }^{41}$ Polysaccharides of this herb were shown to enhance NK cell activity of normal subjects and patients with systemic lupus erythematosus. $^{42}$

LCS101 was also shown to enhance cytokine production, increasing TNF- $\alpha$ secretion from murine macrophages $100-$ fold when compared to untreated controls. TNF- $\alpha$ is a potent antitumor cytokine that enhances the activity of macrophages, NK cells, and cytotoxic T cells. ${ }^{43}$ The polysaccharide fraction PV2IV of Prunella vulgaris has been shown to increase levels of TNF- $\alpha,{ }^{28}$ and Astragalus membranaceus to stimulate markedly macrophage production of TNF- $\alpha$ and IL-6. ${ }^{14}$
Finally, LCS101 was observed to increase production of IFN- $\gamma$, correcting decreased levels following 5-FU treatment, and increasing unaltered levels of the cytokine following exposure to doxorubicin. IFN- $\gamma$ production is induced by $\mathrm{T}$ cells, NK cells, and macrophages, and plays a role in the inhibition of tumor growth, promotion of Th1 immune responses, and differentiation of cytotoxic NK and T cells. Immune-competent mice who lack IFN- $\gamma$ fail to normalize tissue homeostasis and clear low-level microbial infections, resulting in chronic inflammation with an increased incidence of hematological and solid-tissue cancers. ${ }^{44}$ The LCS101 component Lycium chinense has been shown to activate IFN- $\gamma$ gene transcription and protein production, ${ }^{39}$ and the component Citrus reticulate to significantly increase the protein level of IFN- $\gamma$, as well as restoring TNF- $\alpha$ to normal levels. ${ }^{18}$ 
In conclusion, the present study found the botanical compound LCS101 to have a number of effects on both innate and adaptive immune processes, with potential indirect anticancer activity. No side effects were observed in mice treated with the botanical compound, and no negative effects were observed on the response to chemotherapy or tumor mass. Further research is needed in order to understand the molecular immunomodulatory pathways affected by both the individual components and the compound as a whole, as well as the clinical implications for this treatment option.

\section{Disclosure}

No funding was provided for the research. Dr Maimon is a shareholder of LifeBiotics Ltd. All other authors report no conflicts of interest in this work.

\section{References}

1. Burnet FM. Immunological aspects of malignant disease. Lancet. 1967;1:1171-1174.

2. de Visser K, Coussens LM. The interplay between innate and adaptive immunity regulates cancer development. Cancer Immunol Immunother. 2005;54:1143-1152.

3. de Visser KE, Eichten A, Coussens LM. Paradoxical roles of the immune system during cancer development. Nat Rev. 2006;6:24-37.

4. Imada A, Shijubo N, Kojima H, Abe S. Mast cells correlate with angiogenesis and poor outcome in stage I lung adenocarcinoma. Eur Resp J. 2000;15:1087-1093.

5. Takanami I, Takeuchi K, Naruke M. Mast cell density is associated with angiogenesis and poor prognosis in pulmonary adenocarcinoma. Cancer. 2000;88:2686-2692.

6. Benítez-Bribiesca L, Wong A, Utrera D, Castellanos E. The role of mast cell tryptase in neoangiogenesis of premalignant and malignant lesions of the uterine cervix. J Histochem Cytochem. 2001;49:1061-1062.

7. Hardy ML. Dietary supplement use in cancer care: help or harm. Hematol Oncol Clin North Am. 2008;22:581-617.

8. Lu Y, Li CS, Dong Q. Chinese herb related molecules of cancer-cellapoptosis: a minireview of progress between Kanglaite injection and related genes. J Exp Clin Cancer Res. 2008;27:31.

9. Samuels N, Maimon Y, Siegelmann-Danieli N. In reply. Oncologist. 2012;17:742-743. Available from: http://theoncologist.alphamedpress. org/content/17/5.toc.

10. Maimon Y, Karaush V, Yaal-Hahoshen N, et al. Effect of Chinese herbal therapy on breast cancer adenocarcinoma cell lines. J Int Med Res. 2010;38:2033-2039.

11. Yaal-Hahoshen N, Maimon Y, Siegelmann-Danieli N, et al. A prospective, controlled study of the botanical compound mixture LCS101 for chemotherapy-induced hematological complications in breast cancer. Oncologist. 2011;16:1197-1202.

12. Sun Y, Hersh EM, Lee SL, McLaughlin M, Loo TL, Mavligit GM. Preliminary observations on the effects of the Chinese medicinal herbs Astragalus membranaceus and Ligustrum lucidum on lymphocyte blastogenic responses. J Biol Resp Mod. 1983;2:227-237.

13. Wang Y, Qian XJ, Hadley HR, Lau BH. Phytochemicals potentiate interleukin-2 generated lymphokine-activated killer cell cytotoxicity against murine renal cell carcinoma. Mol Biother. 1992;4:143-146.

14. Yoshida Y, Wang MQ, Liu JN, Shan BE, Yamashita U. Immunomodulating activity of Chinese medicinal herbs and Oldenlandia diffusa in particular. Int J Immunopharmacol. 1997;19:359-370.
15. [No authors listed]. Astragalus membranaceus. Monograph. Alt Med Rev. 2003;8:72-77.

16. Kim SH, Jung HN, Lee KY, Kim J, Lee JC, Jang YS. Suppression of TH2-type immune response-mediated allergic diarrhea following oral administration of traditional Korean medicine: Atractylodes macrocephala Koidz. Immunopharmacol Immunotoxicol. 2005;27:331-343.

17. Lee JC, Leeb KY, Sona YO, et al. Stimulating effects on mouse splenocytes of glycoproteins from the herbal medicine Atractylodes macrocephala Koidz. Phytomedicine. 2007;14:390-395.

18. Lee S, Ra J, Song JY, et al. Extracts from Citrus unshiu promote immune-mediated inhibition of tumor growth in a murine renal cell carcinoma model. J Ethnopharmacol. 2011;133:973-979.

19. Yoon T, Cheon MS, Lee AY, et al. Anti-inflammatory activity of methylene chloride fraction from Glehnia littoralis extract via suppression of NF-kappa B and mitogen-activated protein kinase activity. J Pharmacol Sci. 2010;112:46-55.

20. Yoon T, Lee DY, Lee AY, Choi G, Choo BK, Kim HK. Anti-inflammatory effects of Glehnia littoralis extract in acute and chronic cutaneous inflammation. Immunopharmacol Immunotoxicol. 2010;32:663-670.

21. Han SS, Cho CK, Lee YW, Yoo HS. Antimetastatic and immunomodulating effect of water extracts from various mushrooms. J Acupunc Meridian Stud. 2009;2:218-227.

22. Hsu CC, Hsu CL, Tsai SE, Fu TY, Yen GC. Protective effect of Millettia reticulata $\mathrm{Benth}$ against $\mathrm{CCl}(4)$-induced hepatic damage and inflammatory action in rats. J Med Food. 2009;12:821-828.

23. Wong BY, Lau BH, Jia TY, Wan CP. Oldenlandia diffusa and Scutellaria barbata augment macrophage oxidative burst and inhibit tumor growth. Cancer Biother Radiopharmaceut. 1996;11:51-56.

24. Yu B, Yin X, Xu G, Xu L. Quality of tuberous root of Liriope spicata (Thunb.) Lour. var. prolifera Y.T.Ma and Ophiopogon japonicus (L.F.) Ker-Gawl. - comparison of immune function. Zhongguo Zhong Yao Za Zhi. 1991;16:584-585, 638. Chinese.

25. Nizamutdinova IT, Oh HM, Min YN, et al. Paeonol suppresses intercellular adhesion molecule-1 expression in tumor necrosis factor-alpha-stimulated human umbilical vein endothelial cells by blocking p38, ERK and nuclear factor-kappaB signaling pathways. Int Immunopharmacol. 2007;7:343-350.

26. Zhou Z, Lin J, Huo R, et al. Total glucosides of paeony attenuated functional maturation of dendritic cells via blocking TLR4/5 signaling in vivo. Int Immunopharmacol. 2012;14:275-282.

27. Chen X, Zhang L, Cheung PC. Immunopotentiation and anti-tumor activity of carboxymethylated-sulfated $\beta-(1 \rightarrow 3)$-D-glucan from Poria cocos. Int Immunopharmacol. 2010;10:398-405.

28. Fang X, Yu MM, Yuen WH, Zee SY, Chang RC. Immune modulatory effects of Prunella vulgaris L. on monocytes/macrophages. Int J Mol Med. 2005;16:1109-1116.

29. Fang X, Chang RC, Yuen WH, Zee SY. Immune modulatory effects of Prunella vulgaris L. Int J Mol Med. 2005;15:491-496.

30. Sun HX, Qin F, Pan YJ. In vitro and in vivo immunosuppressive activity of Spica Prunellae ethanol extract on the immune responses in mice. J Ethnopharmacol. 2005;101:31-36.

31. Dai Z, Liu X, Ji Z, et al. The effect-enhancing and toxicityreducing action of the extract of herba Scutellariae barbatae for chemotherapy in hepatoma H22 tumor-bearing mice. JTrad Chin Med. 2008;28:205-210.

32. Ramachandran C, Wilk BJ, Hotchkiss A, Chau H, Eliaz I, Melnick SJ. Activation of human T-helper/inducer cell, T-cytotoxic cell, B-cell, and natural killer (NK)-cells and induction of natural killer cell activity against K562 chronic myleoid leukemia cells with modified citrus pectin. BMC Complement Altern Med. 2011;11:59.

33. Funada Y, Noguchi T, Kikuchi R, Takeno S, Uchida Y, Gabbert HE. Prognostic significance of CD8+ T cell and macrophage peritumoral infiltration in colorectal cancer. Oncol Report. 2003;10:309-313.

34. Nakakubo Y, Miyamoto M, Cho Y, et al. Clinical significance of immune cell infiltration within gallbladder cancer. $\mathrm{Br}$ J Cancer. 2003;89:1736-1742. 
35. Oshikiri T, Miyamoto M, Shichinohe T, et al. Prognostic value of intratumoral CD8+ T lymphocyte in extrahepatic bile duct carcinoma as essential immune response. J Surg Oncol. 2003;84:224-228.

36. Wakabayashi O, Yamazaki K, Oizumi S, et al. CD4(+) T cells in cancer stroma, not CD8(+) $\mathrm{T}$ cells in cancer cell nests, are associated with favorable prognosis in human non-small cell lung cancers. Cancer Sci. 2003;94:1003-1009.

37. Wang DC. Influence of Astragalus membranaceus (AM) polysaccharide FB on immunologic function of human periphery blood lymphocyte. Zhonghua Zhong Liu Za Zhi. 1989;11:180-183. Chinese.

38. Jiao Y, Wen J, Yu X. Influence of flavonoid of Astragalus membranaceus's stem and leaves on the function of cell mediated immunity in mice. Zhongguo Zhong Xi Yi Jie He Za Zhi. 1999;19:356-358. Chinese.

39. Chen Z, Kwong Huat Tan B, Chan SH. Activation of T lymphocytes by polysaccharide-protein complex from Lycium barbarum L. Int Immunopharmacol. 2008;8:1663-1671.
40. Lee SK, Gasser S. The role of natural killer cells in cancer therapy Front Biosci (Elite Ed). 2010;2:380-391.

41. Mills S, Bone K. Principles and Practice of Phytotherapy. Edinburgh: Churchill Livingstone; 2000.

42. Zhao XZ. Effects of Astragalus membranaceus and Tripterygium hypoglancum on natural killer cell activity of peripheral blood mononuclear in systemic lupus erythematosus. Zhongguo Zhong Xi Yi Jie He Za Zhi. 1992;12:669-671. Chinese.

43. Sabel MS, Arora A, Su G, Mathiowitz E, Reineke JJ, Chang AE. Synergistic effect of intratumoral IL-12 and TNF-alpha microspheres: systemic anti-tumor immunity is mediated by both CD8+ CTL and NK cells. Surgery. 2007;142:749-760.

44. Enzler T, Gillessen S, Manis JP, et al. Deficiencies of GM-CSF and interferon $\gamma$ link inflammation and cancer. J Exp Med. 2003;197: 1213-1219.

\section{Publish your work in this journal}

OncoTargets and Therapy is an international, peer-reviewed, open access journal focusing on the pathological basis of all cancers, potential targets for therapy and treatment protocols employed to improve the management of cancer patients. The journal also focuses on the impact of management programs and new therapeutic agents and protocols on

\section{Dovepress}

patient perspectives such as quality of life, adherence and satisfaction. The manuscript management system is completely online and includes a very quick and fair peer-review system, which is all easy to use. Visit http://www.dovepress.com/testimonials.php to read real quotes from published authors.

Submit your manuscript here: http://www.dovepress.com/oncotargets-and-therapy-journal 